\title{
T2 (Observed)-Weighted Imaging
}

National Cancer Institute

\section{Source}

National Cancer Institute. T2 (Observed)-Weighted Imaging. NCI Thesaurus. Code C156447.

MRI imaging based on the observed T2 relaxation time of tissues. 